\title{
Konya bölgesi popülasyonunda CAPN10 genindeki SNP-43 polimorfizmi Tip 2 Diabetes riski ile ilișkilidir
}

\section{SNP-43 polymorphism in CAPN10 gene is associated with Type 2 Diabetes risk in Konya region population}

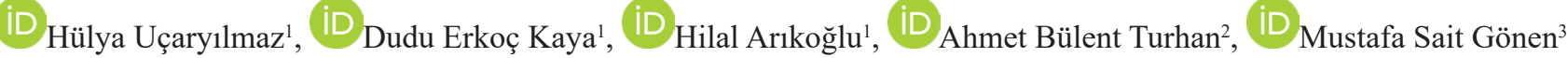

${ }^{1}$ Selçuk Üniversitesi Tıp Fakültesi Tıbbi Biyoloji AD, Konya, Türkiye

${ }^{2}$ Aksaray Üniversitesi, Tıp Fakültesi Tıbbi Biyoloji AD, Aksaray, Türkiye

${ }^{3}$ İstanbul Üniversitesi-Cerrahpaşa, Cerrahpaşa Tıp Fakültesi Endokrinoloji ve Metabolizma Hastalıkları BD, İstanbul, Türkiye.

Öz

Amaç: Kalpain-10 (CAPN10), Ca+2 bağımlı intrasellüler sistein proteazlar ailesinin atipik bir üyesidir. Birçok dokuda eksprese edilir ve başta insülin sekresyonu ve aktivitesi olmak üzere çok çeşitli hücresel fonksiyonlar için gereklidir. Tanımlanan ilk Tip 2 diyabet (T2D) yatkınlık genidir. Çalışmamızda bir Türk popülasyonunda CAPN10 gen polimorfizmleri (SNP-44, -43 ve -137) ile artmış T2D riski arasındaki ilişkinin analiz edilmesi amaçlandı.

Gereç ve Yöntem: Çalışmaya 149 T2D'li hasta ve 48 sağlıklı birey dahil edildi. Genotiplendirme PCR-SSCP tekniği kullanılarak yapıldı, dizi analizi ile doğrulandı. CAPN10 genotiopleri ile T2D gelişimi ve klinik özellikler arasındaki ilişki istatistiksel olarak analiz edildi.

Bulgular: Hastalıkla genotip arasındaki ilişkiyi belirlemek için yapılan odds analizi sonuçlarına göre; SNP-44 ile hastalık arasında ilişki gözlenmezken (OR: 1.417 CI:0.452-4.436, $\mathrm{P}=0.740$ ), SNP-43 ile hastalık arasında anlamlı ilişki bulundu (OR: 0.455 CI:0.235-0.881, $\mathrm{P}=0.028$ ). SNP-137 genotip dağılımı tüm hasta ve kontrol bireylerde C/C olarak tespit edildi. Taranan SNP'ler ile klinik parametreler arasında herhangi bir ilişki bulunmadı ( $\mathrm{P}>0.05)$.

Sonuç: Sonuçlarımıza göre; CAPN10 genindeki SNP-43, Türk popülasyonunda T2D gelişimi açısından bir risk faktörüdür.

Anahtar Kelimeler: Tip 2 Diyabet, Kalpain-10, polimorfizm

Abstract

Objective: Calpain-10 (CAPN10) is an atypical member of the Ca2+ dependent intracellular cysteine proteases family. It is expressed in many tissues and is essential for multiple cellular functions such as insulin secretion and activity. It is the first type 2 diabetes susceptibility gene identified. In our study, we aimed to analyze the relationship between CAPN10 gene polymorphisms (SNP-44, -43 and -137) and increased type 2 diabetes risk in a Turkish population.

Material and Methods: 149 T2D patients and 48 healthy individuals were included in the study. Genotyping was performed using the PCR-SSCP technique, confirmed by DNA sequence analysis. The association between CAPN10 genotypes and T2D development and clinical features was statistically analyzed.

Results: According to the results of the odds analysis, while no correlation was observed between SNP-44 and disease (OR: 1.417 CI: 0.452-4.436, P=0.740), a significant correlation was found between SNP-43 and disease (OR: 0.455 CI: 0.235-0.881, $\mathrm{P}=0.028$ ). SNP-137 genotype distribution was detected as $\mathrm{C} / \mathrm{C}$ in all patient and control individuals. No correlation was found between the scanned SNPs and clinical parameters $(\mathrm{P}>0.05)$.

Conclusion: According to our results; SNP-43 in the CAPN10 gene is a risk factor for the development of T2D in the Turkish population.

Key words: Type 2 Diabetes, Calpain-10, polymorphism

XII. Ulusal Tıbbi Biyoloji ve Genetik Kongresi’de (30.10.2011-Antalya) poster olarak sunulmuştur.

Yazışma Adresi: Hülya Uçaryılmaz, Selçuk Üniversitesi, Tıp Fakültesi Tıbbi Biyoloji AD, Alaeddin Keykubat Kampüsü, Konya, Türkiye

E-Posta: hulyaozdemir1@gmail.com

Alınma tarihi: 02.08.2021 / Kabul tarihi: 20.08.2021 / Yayımlanma tarihi: 20.09.2021

CAPN10 genindeki SNP-43 polimorfizmi ve Tip 2 Diabetes - Uçaryılmaz ve ark.

Genel Tip Derg 2021;31(3)290-294 


\section{Giriş}

Diabetes Mellitus (DM), pankreasta beta $(\beta)$ hücrelerinin yeterli insülin üretememesi ve/veya insülinin hedef hücrelerde etkisiz kullanımı sonucu kandaki kronik yüksek glukoz düzeylerinden kaynaklanır (1). Genel olarak DM, tip 1 diyabet (T1D) ve tip 2 diyabet (T2D) olmak üzere iki ana tipten oluşur.

T2D toplumda en yaygın görülen diyabet tipidir. T2D'de görülen insülin direnci; genetik yatkınlık, obezite, hareketsiz yaşam tarzı, stres koşulları, sağlıksız beslenme ve yaşlanma gibi faktörler ile ilişkilidir $(2,3)$. T2D hastalarının yarısından fazlası, 10 yıllık insülin direncinden sonra ortaya çıkan pankreas $\beta$ hücrelerinin işlev bozukluğu nedeniyle insülin tedavisine ihtiyaç duyar $(4,5)$. T2D'de uzun süreli kronik insülin direnci, ateroskleroz gibi makrovasküler komplikasyonların yanı sıra nefropati, nöropati ve retinopati gibi mikrovasküler komplikasyonlar dahil olmak üzere çeşitli sonuçlara yol açar (6).

T2D'nin gelişiminde çevresel ve genetik etkenlerin etkileşimi söz konusu olduğundan hastalığın patogenezi oldukça karmaşıktır. Ayrıca hastalığın genetik alt yapısı; tek bir genden ziyade poligenik profil gösterdiğinden genetik risk faktörlerinin açık bir şekilde ortaya koyulabilmesi de oldukça zorlayıcıdır. Genom Boyu ilişki çalışmaları ve aday gen çalışmaları sonucu birçok gen T2D gelişiminden sorumlu tutulmaktadır $(7,8)$. Aday gen yaklaşımına göre hastalıkla ilişkili olduğu belirlenen genler pankreatik $\beta$-hücre fonksiyonu, insülin aktivitesi, lipid metabolizması ve enerji homeostazında yer alan proteinleri kodlayan genler olarak sınıflandırılır (9). Aday genlerden biri olarak öne çıkan Kalpain-10 geni (CAPN10), Ca+2 bağımlı intrasellüler sistein proteazlar ailesinin atipik bir üyesidir. Kalpain aktivitesi, hücre sinyali, apoptoz, ekzositoz, mitokondriyal metabolizma ve hücre iskeletinin yeniden şekillenmesi gibi çeşitli hücresel süreçlerde rol oynamaktadır. Yapılan çalışmalar, kalpain ekspresyonunun bozulmasının ve farklı kalpain aile üyelerinin aktivitesinin çeşitli patolojilerde rol oynadığını göstermiştir (10).

İnsan genomunda kalpain ailesi proteinlerinin üyelerini kodlayan 15 kalpain geninden biri olan CAPN10, 2. kromozomun q37.3 bölgesine yerleşiktir ve $31 \mathrm{~kb}$ büyüklügündedir. İnsan CAPN10 geni, alternatif kesip ekleme ile en az 8 izoform üreten 15 ekzondan oluşmaktadır (kalpain-10a-h). Dokularda en yaygın bulunan ve en uzun izoformu olan kalpain-10a, 672 amino asitlik bir proteini kodlar (11). Kalpain-10 proteini; kalp, iskelet kası, karaciğer, pankreas adacık hücreleri ve yağ dokularında eksprese edilen, sitozol ve mitokondride lokalize, lizozomal olmayan nötr bir sistein proteazdır (12).

Kalpain-10; insülin sekresyonunun, pankreatik $\beta$-hücre apoptozunun ve insülin aracılı glukoz metabolizmasının düzenlenmesinde rol oynamaktadır (13-15). Bu nedenle gende yer alan polimorfizmler, T2D gelişimi ile ilişkilendirilmektedir. CAPN10 geninde bulunan ve T2D ile en yaygın ilişkilendirilen polimorfizmlerden SNP-44 (rs2975760, T/C, intron 3), SNP-43 (rs3792267, G/A, intron 3), SNP-19 (rs3842570, ins/del32bp, intron 6) ve SNP63 (rs5030952, $\mathrm{C} / \mathrm{T}$, intron 13) CAPN10'un kodlamayan bölgelerinde bulunurlar ve Kalpain-10'un transkripsiyonel düzenlenmesini etkilerler $(11,16)$.

Bu çalışmada, CAPN10 geninde bulunan ve T2D gelişimi ile ilişkili olduğu düşünülen polimorfizmlerden SNP-44, SNP-43 ve SNP-137 Türk popülasyonunda hastalık ile ilişkisi bakımından taranmıştır.

\section{Gereç ve Yöntem}

\section{Hasta Seçimi}

Çalışmaya, Selçuk Üniversitesi Meram Tıp Fakültesi Dahiliye Anabilim Dalı Endokrinoloji Bilim Dalı ve Konya Diyabet Cemiyetine başvuran T2D tanısı almış 149 hasta ve kontrol grubu olarak 48 sağlıklı birey dahil edildi. Hasta grubuna dahil edilecek bireyler; 40 yaş üzerinde olan, insülin kullanmayan, vücut kitle indeksinin (VKİ) 30'un altında olan ve akraba olmayanlar arasından seçilirken; kontrol grubu, ailesinde diyabet hikayesi olmayan, oral glukoz tolerans testi (OGTT) normal çıkan ve 40 yaşın üzerindeki gönüllü bireylerden oluşturuldu. Çalışmaya dahil edilen hastalar ADA kriterlerine göre belirlendi. ADA kriterlerine göre: 1-Günün herhangi bir saatinde yapılan ölçümde kan şekerinin $\geq 200 \mathrm{mg} / \mathrm{dl}$, 2-Açlık kan şekerinin iki kez $\geq 126 \mathrm{mg} / \mathrm{dl}, 3$-OGTT'de 2 . saat kan şekerinin $\geq 200$ $\mathrm{mg} / \mathrm{dl}$ ve $4-\mathrm{HbA} 1 \mathrm{c}>\% 6,5$ olan bireyler T2D hastası olarak kabul edilmiştir. Çalışma etik kurul tarafından onaylandı (24.04.2009/126) ve çalışmaya dahil edilen hastalardan "bilgilendirilmiş olur formu" alınd.

\section{Biyokimyasal Tetkikler}

Biyokimyasal tetkiklerde kullanılmak üzere falkon tüplerine $10 \mathrm{ml}$ kan alındı. Hasta ve kontrol grubu bireylerin glukoz, insülin, HbA1c, C-peptid, kolesterol, HDL kolesterol, LDL kolesterol, trigliserid düzeyleri ölçüldü. Prediyabet olabileceği düşünülen kontrol grubu bireylere 9-16 saatlik açlıktan sonra sabah saat 8'de OGTT yapıldı. OGTT için, $300 \mathrm{ml}$ suda eritilen 75 gr glukoz bir limon sıkılarak limonata şeklinde içirildi. OGTT yapılmadan önce ve glukoz içirildikten sonra 2. saatte kan örneği alınarak glukoz ve insülin düzeylerine bakıldı. Bozulmuş glukoz toleransı ve insülin direnci tespit edilenler çalışmaya alınmadı.

Hasta ve kontrol grubundaki bireylerin insülin direncinin belirlenmesi için HOMA-IR (Homeostasis Model of Assessment - Insulin Resistance) hesaplaması aşağıdaki formüle göre yapıldı. HOMAIR değeri 2'nin üzerinde olan bireyler insüline dirençli kabul edildi. HOMA-IR $=$ açlık insülin $(\mathrm{mU} / \mathrm{L}) \times$ açlık glukoz $(\mathrm{mmol} / \mathrm{L}) / 22.5$

\section{Genotiplendirme}

DNA izolasyonu için EDTA'lı tüplere 5-6 cc periferik kan alındı. Genomik DNA, standart proteinaz K ve SDS prosedürü kullanılarak periferik kan lökositlerinden izole edildi. Kalpain-10 geninin nükleotid dizisi, GenBank ${ }^{\mathrm{TM}}$ veri tabanından elde edildi (erişim no.NM_023083). Çalışmada CAPN10 geninde bulunan Tablo1'de özellikleri verilen intronik SNP-44 (g.4841, T/C) ile SNP-43 (g.4852, G/A) ve ekzonik SNP-137 (g.9956, C/T - Arg555Cys)'nin taranmas1 hedeflendi. Hedef SNP'lerin genotiplendirilmesi PCR-SSCP ve dizi analizi teknikleri kullanılarak gerçekleştirildi. Hedef SNP-44, -43 ve -137 için kullanılan primerler, www.idtdna.com adresindeki çevrim içi program kullanılarak tasarland. İntron 3 bölgesinde birbirinden 11 bç uzaklıkta bulunan SNP-44 ve SNP-43 genotiplemesi için ileri primer 5'-AGAGAGTTTCTGTGTGTGGGCAGA-3' ve geri primer 5'-AAATCGTCCAACCGCTGCCTCAAT-3' kullanıldı. 155 bç büyüklüğünde ürün elde edildi.SNP-137 genotiplemesi için ileri primer 5'-CCTCCCATGTTTGTCTTCTTGGCA ve geri primer 5'-TGCCTGGAAGATATGGAAGCCGAT-3' kullanılarak 290 bç büyüklüğünde ürün elde edildi.

PCR (polimeraz zincir reaksiyonu) reaksiyon karışımı, 1X PCR 
tamponu, $0.4 \mathrm{mM}$ ileri ve geri primer, $0.6 \mathrm{mM}$ deoksinükleosit trifosfatlar, 0,1 U Taq polimeraz ve 50-100 ng genomik DNA olacak şekilde $15 \mu \mathrm{L}^{\prime}$ lik bir hacimde hazırlandı. PCR reaksiyonları için; termocycler cihazı; $94{ }^{\circ} \mathrm{C}$ 'de 5 dakika ilk denatürasyon, $94{ }^{\circ} \mathrm{C}$ 'de 30 saniye denatürasyon, her bir primer için farklı sıcaklıkda $30 \mathrm{~s}$ bağlanma ve $72{ }^{\circ} \mathrm{C}$ 'de $30 \mathrm{~s}$ uzama şeklinde 35 döngü ve $72{ }^{\circ} \mathrm{C}$ 'de 2 dakika son uzama adımları olacak şekilde programlandı.

Tablo 1: CAPN10 geninde taranan SNP'lerin özellikleri

\begin{tabular}{|l|l|l|l|l|}
\hline $\begin{array}{l}\text { SNP } \\
\text { rs numarası }\end{array}$ & Polimorfizm & Bölge & Allel & Nükleotid \\
\hline rs 2975760 & SNP-44 & İntron 3 & T/C & 4841 \\
\hline rs 3792267 & SNP-43 & İntron 3 & G/A & 4852 \\
\hline- & SNP-137 & Ekzon 10 & C/T (Arg555Cys) & 9956 \\
\hline
\end{tabular}

\section{SSCP (Single-Strand Conformation Polymorphism) Analizi}

Amplifikasyonun ardından, PCR-SSCP ile değerlendirilecek örnekler, formamid tamponu ( $\% 80$ formamid, $\% 0.1$ bromofenol mavisi, $\% 0.1$ ksilen siyanol, 10 mM EDTA) ile 5 kat seyreltildi, $95{ }^{\circ} \mathrm{C}$ 'de 10 dakika denatüre edildi ve elektroforezden önce buz üzerinde soğutuldu. Örnekler, 10X Tris-borat-EDTA (TBE) tamponunda oda sıcaklığında 15-18 saat boyunca 2-10 W'da elektroforezde yürütüldü ve gümüş boyama ile bantların görüntülenmesi yapıldı. DNA örnekleri, SSCP jeli üzerindeki göç profillerine göre gruplandı ve seçilen örneklerin DNA dizi analizi ile genotiplendirme yapıldı.

\section{Dizi Analizi}

SSCP ile genotipleme yapıldıktan sonra SNP'lere özgü farklı genotip gruplarından örnekler seçilerek dizi analizine gönderildi (İontek, Türkiye ve Macrogen, Kore). Dizi analizi sonuçları Java programı ile pikler şeklinde görüntülenerek değerlendirildi ve NCBI blast programı ile gen bankasındaki dizilerle eşleştirildi. Blast sonuçları ve pik görüntüleri dikkatli bir biçimde karşılaştırılarak değiş̧iklikler değerlendirildi ve genotiplendirme doğrulandı.

\section{İstatistiksel Analiz}

Verilerin istatistiki analizi SPSS 21.0 programı kullanılarak yapıldı. Biyokimyasal veriler ortalama \pm standart sapma olarak verildi. Klinik verilerin karşıllaştırılmasında normal dağılan gruplar için Student-t testi, normal dağılmayan gruplar için Mann-Whitney U testi kullanıldı. SNP'lerin genotip dağılımları ve hastalık ilişkileri odds oranları hesaplanarak analiz edildi. Genotiplerin HardyWeinberg (HW) dengesi bakımından analizi Ki- kare testi ile yapıldı. SNP genotiplerinin klinik verilerle ilişkisi Mann-Whitney U testi kullanılarak değerlendirildi. Tüm analizler için, P değeri $<0.05$ istatistiksel olarak anlamlı kabul edildi.

\section{Bulgular}

\section{Demografik ve Klinik Özellikler}

Çalışmaya ADA kriterlerine göre T2D tanısı almış 149 hasta ve kontrol grubu olarak 48 sağlıklı birey dahil edildi. Hasta ve kontrol grubundaki bireylerin klinik ve biyokimyasal verileri Tablo 2'de özetlendi.

Kontrol grupları ile karşılaştırıldığında, T2D bireylerin açlık glukoz, HbA1c, HOMA-IR düzeyleri anlamlı şekilde farklı bulundu ( $\mathrm{P}=0.001)$. OGTT sonuçlarına göre yapılan değerlendirmede, 2. saat açlık plazma glukoz düzeyi >200 olan bireyler diyabetik olarak düşünüldü, 140-200 aralığında açlık glukozu olan diğerleri ise bozulmuş glukoz toleransına sahip oldukları düşünülerek kontrol grubuna alınmadı. Hasta ve kontrol grubu arasında vücut kitle indeksi, açlık insülin ve c-peptid değerleri bakımından anlamlı farklılık gözlenmedi $(\mathrm{P}>0.05)$.

Tablo 2: T2D hastaları ve kontrol gruplarının klinik özellikleri

\begin{tabular}{llcc} 
& \multicolumn{1}{c}{ T2D } & Kontrol & P \\
& \multicolumn{1}{c}{$(\mathbf{n = 1 4 9 )}$} & $(\mathbf{n = 4 8 )}$ & \\
\hline Cinsiyet (E/K) & $98 / 51$ & $27 / 21$ & 0.323 \\
Yaş & $55.93 \pm 9.00$ & $43.62 \pm 12.68$ & 0.001 \\
Vücut Kitle İndeksi (kg/m²) & $26.49 \pm 2.90$ & $26.62 \pm 2.98$ & 0.469 \\
Açlık glukoz (mg/d) & $162.15 \pm 68.49$ & $94.31 \pm 13.29$ & 0.001 \\
Açlık insülin (Mıu/l) & $9.05 \pm 4.71$ & $8.47 \pm 4.27$ & 0.370 \\
HbA1c (\%) & $7.59 \pm 2.54$ & $5.36 \pm 0.60$ & 0.001 \\
c-peptid & $2.31 \pm 1.22$ & $4.15 \pm 4.20$ & 0.126 \\
HOMA-IR & $3.47 \pm 2.08$ & $1.98 \pm 1.05$ & 0.001 \\
\hline
\end{tabular}

T2D: Tip 2 diyabet

\section{CAPN10 Genindeki SNP'lerin Belirlenmesi}

SNP-44 (T/C) ve SNP-43 (G/A) intron 3'de lokalize olmuştur. Birbirlerinden 11 bç uzaklıkta bulunmaktadırlar. Buna göre; SNP44 için genotip sıklığı hasta grubunda \%88.6 (T/T), \%11.4 (T/C) ve kontrol grubunda \%91.7 (T/T), \%8.3 (T/C) olarak hesaplandı. SNP44'de C/C genotipi gözlenmedi. SNP-43 için hasta grubunda \% 63.1 (G/G), \%36.9 (G/A) ve kontrol grubunda ise \%43.8 (G/G), \%56.3 (G/A) olarak hesaplandi. SNP-43'de ise A/A genotipi gözlenmedi. SNP-137 (C/T - Arg555Cys) ekzon 10'da lokalize olmuştur. PCRSSCP sonuçlarında tüm bireylerde aynı göç profili gözlendi. Dizi analizi sonuçları ile bu göç profilinin $\mathrm{C} / \mathrm{C}$ genotipi olduğu gösterildi. SNP-137'de C/T ve T/T genotipleri gözlenmemiş olup tüm hasta ve kontrol bireylerimiz $\mathrm{C} / \mathrm{C}$ genotipinde olduğu belirlendi (Tablo 3).

Tablo 3: CAPN10 geninde araştırılan SNP'lerin genotip dağılımı ve T2D ilişkisi

\begin{tabular}{|c|c|c|c|c|c|c|}
\hline SNP & Genotip & $\begin{array}{l}\text { T2D } \\
\text { n (\%) }\end{array}$ & $\begin{array}{l}\text { Kontrol } \\
\text { n (\%) }\end{array}$ & OR (\%95 CI) & $\chi^{2}$ & $\mathbf{P}$ \\
\hline \multirow{3}{*}{ SNP-44 } & $\mathrm{T} / \mathrm{T}$ & $\begin{array}{c}132 \\
(88.6)\end{array}$ & 44 (91.7) & \multirow{3}{*}{$\begin{array}{c}1.417 \\
(0.452-4.436)\end{array}$} & \multirow{3}{*}{0.110} & \multirow{3}{*}{0.740} \\
\hline & $\mathrm{T} / \mathrm{C}$ & $17(11.4)$ & $4(8.3)$ & & & \\
\hline & $\mathrm{C} / \mathrm{C}$ & - & - & & & \\
\hline \multirow{3}{*}{ SNP-43 } & $\mathrm{G} / \mathrm{G}$ & $94(63.1)$ & $21(43.8)$ & \multirow{3}{*}{$\begin{array}{c}0.455 \\
(0.235-0.881)\end{array}$} & \multirow{3}{*}{4.819} & \multirow{3}{*}{0.028} \\
\hline & $\mathrm{G} / \mathrm{A}$ & $55(36.9)$ & $27(56.3)$ & & & \\
\hline & $\mathrm{A} / \mathrm{A}$ & - & - & & & \\
\hline \multirow{3}{*}{ SNP-137 } & $\mathrm{C} / \mathrm{C}$ & $\begin{array}{c}149 \\
(100.0)\end{array}$ & $48(100.0)$ & \multirow{3}{*}{\multicolumn{3}{|c|}{ * }} \\
\hline & $\mathrm{C} / \mathrm{T}$ & - & - & & & \\
\hline & $\mathrm{T} / \mathrm{T}$ & - & - & & & \\
\hline
\end{tabular}

* Diğer genotipler gözlenmediği için OR hesaplaması yapılamadı.

\section{T2D ile Genotip İlişkisi}

Hasta ve kontrol gruplarında genotip dağılımları Hardy Weinberg dengesindeydi $(\mathrm{P}>0.05)$. Hastalıkla genotip arasındaki ilişkiyi belirlemek için yapılan odds analizi sonuçlarına göre; SNP-44 ile hastalık arasında ilişki gözlenmezken (OR: 1.417 CI:0.452-4.436, 
$\mathrm{P}=0.740$ ), SNP-43 ile hastalık arasında anlamlı ilişki bulundu (OR: 0.455 CI:0.235-0.881, P=0.028). SNP-137 genotip dağ 11 lım bakımından tüm hasta ve kontrol bireylerde $\mathrm{C} / \mathrm{C}$ olarak tespit edildi (Tablo 3).

\section{Genotip-Fenotip İlişkisi}

SNP-44 ve SNP-43 genotipleri açlık glukoz, açlık insülin, HbAlc, HOMA-IR, c-peptid ve VKİ üzerine etkileri bakımından değerlendirildiğinde istatistiksel olarak anlamlı bir ilişki bulunmad $(\mathrm{P}>0.05)$ (Tablo 4).

Tablo 4: T2D hastalarında CAPN10 genindeki SNP'lerin genotip dağılımı ile klinik özellikler arasındaki ilişki

\begin{tabular}{|l|l|l|l|l|l|l|}
\hline & Açlık glukoz & $\begin{array}{c}\text { Açlık } \\
\text { Insülin }\end{array}$ & $\begin{array}{c}\text { HOMA- } \\
\text { IR }\end{array}$ & HbA1c & c-peptid & \multicolumn{1}{|c|}{ VKI } \\
\hline SNP-44 & & & & & & \\
\hline T/T & $145.32 \pm 65.65$ & $8.98 \pm 4.64$ & $3.17 \pm 2.03$ & $7.10 \pm 2.46$ & $2.71 \pm 2.41$ & $25.51 \pm 5.77$ \\
\hline T/C & $165.61 \pm 70.69$ & $8.91 \pm 4.74$ & $3.18 \pm 1.65$ & $7.33 \pm 2.33$ & $2.62 \pm 1.44$ & $25.26 \pm 6.76$ \\
\hline $\mathbf{P}$ & 0.558 & 0.894 & 0.808 & 0.939 & 0.499 & 0.663 \\
\hline SNP-43 & & & & & & \\
\hline G/G & $149.96 \pm 60.89$ & $9.13 \pm 4.23$ & $3.31 \pm 1.91$ & $7.09 \pm 2.32$ & $2.39 \pm 1.65$ & $25.38 \pm 5.76$ \\
\hline G/A & $143.58 \pm 73.36$ & $8.75 \pm 5.18$ & $2.97 \pm 2.12$ & $7.17 \pm 2.61$ & $3.14 \pm 3.00$ & $25.64 \pm 6.02$ \\
\hline $\mathbf{P}$ & 0.124 & 0.325 & 0.085 & 0.900 & 0.135 & 0.245 \\
\hline
\end{tabular}

VKİ: vücut kitle indeksi

\section{Tartışma ve Sonuç}

T2D, genetik ve çevresel faktörlerin etkileşimi ile gelişen, sebep olduğu komplikasyonları ile yaşam kalitesini olumsuz etkileyen bir halk sağlığı problemidir. Giderek artan görülme sıklığı ile dünyada en yaygın görülen kronik hastalıklardan biridir. Diyabette daha iyi metabolik kontrol sağlamak ve diyabetle ilişkili mikro ve makrovasküler komplikasyonlar yanı sıra ortaya çıkan yaşam kalitesi bozuklukları ve psikososyal zorlukların da önlenebilmesi için yeni tanı ve tedavi stratejilerin geliştirilmesi amacıyla oldukça yoğun çaba sarf edilmektedir.

Diyabet gelişim riskinin öngörülebilmesi ve risk altındaki bireylerin önceden belirlenebilmesi halinde alınacak önlemlerle hastalığın ortaya çıkışının engellenmesi ya da ötelenmesi mümkün olabilecektir T2D'in gelişiminde genetik zemin önemli bir risk faktörüdür. Ancak monogenik hastalıkların aksine T2D'in poligenik kalıtımı, genetik risk faktörlerinin belirlenmesinde zorluklara sebep olmaktadır. Farklı yaklaşımlarla ortaya konan birçok gen T2D gelişiminden sorumlu tutulmaktadır.

CAPN10 geni, bağlantı çalışmaları sonucu T2D ile ilişkili olduğu rapor edilen ilk aday gendir (11). Takip eden çalışmalarla birlikte CAPN10 genindeki SNP-19, -43, -44 ve -63 polimorfizmleri T2D ile ilişkili olduğu düşünülen varyantlar olarak rapor edildi (16-21). Horikawa ve arkadaşlarının Meksikalı-Amerikalı, Bosnalı, Finlandiyalı ve Alman popülasyonunu içeren farklı gruplarda yaptıkları çalışma sonuçlarına göre SNP-43 ve SNP-63 ve SNP-19 polimorfizmlerinin Meksikal1Amerikalılarda, SNP-43 ve SNP-63'ün ise Boşnak ve Finlandiya popülasyonlarında T2D gelişim riskini arttırdığını bildirdiler
$(11,22,23)$. Horikawa ve arkadaşları SNP- 44'ün bir güçlendirici (enhancer) elementte lokalize olduğunu ve CAPN10 ekspresyonunu düzenlediğini bildirmişlerdir (11).

CAPN10 geninin T2D gelişimine ilişkin etkisi ilk kez bildirildikten sonra, çok farklı etnik gruplarda yapılan ilişki çalışmalarında bazı popülasyonlarda CAPN10 genindeki polimorfizmlerin T2D riskini arttırdığına dair sonuçlar bildirilirken bir kısmında ise herhangi bir ilişki saptanamamıştır. Bizim çalışmamızda SNP-44 ve T2D arasında ilişki bulunmazken SNP-43'ün hastalıkla ilişkili olduğu tespit edildi.

İngiliz popülasyonunda yapılan bir çalışmada değerlendirilen dört CAPN10 gen polimorfizminden SNP-43, -19 ve -63'ün T2D ile ilişkili olmadığ 1 tespit edilmekle birlikte aile bazlı yapılan bu çalışmada SNP-44 C allelinin hastalıktan etkilenen nesillere beklenenden daha fazla aktarıldığı gözlemlendi ve SNP-44 gen polimorfizminin T2D gelişimindeki önemi ortaya koyuldu (17). Evans ve arkadaşları (17) bu çalışmada; kodlanan bölgede SNP-136 (L34V), SNP-110 (T504A), SNP-137 (R555C) ve SNP-58 (V666I) olmak üzere 4 farklı polimorfizmin daha bulunduğunu, ayrıca SNP-44'ün SNP-110 ile çok iyi bir şekilde bağlantı dengesizliğinde (linkage disequilibrium) olduğunu gösterdiler (17). Evans ve arkadaşlarının aksine Horikawa ve arkadaşları Meksikalı-Amerikalı popülasyonunda SNP-110 polimorfizminin çok seyrek bunduğunu, aynı toplumda SNP-137 polimorfizminin ise görülmediğini tespit ettiler (11). Bu çalışma ile uyumlu olarak bizim popülasyonumuzda da SNP-137 polimorfizmi saptanmadı, tüm hasta ve kontrol bireylerin $\mathrm{C} / \mathrm{C}$ genotipi taşıdığ 1 gözlendi.

Tsai ve ark'nın Polinezya-Samoa halkında, Rasmussen ve ark'nın İskandinav popülasyonunda, Fingerlin ve ark'nın Finlandiya popülasyonunda, Elbein ve ark'nın Kafkaslar üzerinde yaptıkları ilişki çalışmalarında CAPN10 gen polimorfizmlerinin T2D riskini arttırdığına dair bulgu saptanmadı (24-27). Bununla birlikte Elbein ve ark. SNP-19 ve SNP-63'ün yüksek açlık insülin düzeyi ile ilişkili olduğunu rapor ettiler (25). Ortho-Malender ve ark.'nın Finlandiya popülasyonundaki çalışmalarında SNP-44 G alelinin ve SNP-63 T alelinin T2D riskini arttırdığı ayrıca CAPN10 genindeki bu genetik varyantların yüksek serbest yağ asitleri ve insülin direnci ile ilişkili olduğu rapor edildi (28). Cassell ve ark.'nın Güney Hindistan popülasyonunda SNP-44, $-43,-19,-63$ polimorfizmlerinin T2D riski ile ilişkisini değerlendirdikleri çalışmalarında, bozulmuş açlık glukozu ve bozulmuş glukoz toleranslı olgularda SNP-63 T allelinin istatistiksel olarak anlamlı düzeyde fazla gözlendiği bildirildi (18).

Çalışmamızda SNP-44, -43 ve -137 polimorfizmleri ile açlık glukoz, açlık insülin ve diğer biyokimyasal parametreler ile arasında anlamlı bir ilişki saptanmadı.

Japon popülasyonda yapılan SNP-44 ve -43'ün T2D riski ile ilişkisinin araştırıldığ çalışmada bu SNP'lerin genotip kombinasyonun gruplar arasında herhangi bir farklılığa neden olmadığı ayrıca bu SNP'lerin obezite ve hipertansiyon fenotipleri üzerinde de etkisinin olmadiğ saptanmakla birlikte SNP-43 (G/G) ve SNP-44 (T/T) genotip kombinasyonunun yüksek serum kolesterol düzeyi için bir risk faktörü olduğu gözlendi (29). Bir başka Japon popülasyonda ise CAPN10 genindeki SNP-43'ün T2D metabolik özelliklerini etkilemediği bildirildi (30).

21 popülasyon temelli ve 5 ailesel temelli çalışmanın meta-analiz sonuçlarına göre; Popülasyon temelli çalışmada, SNP-43 ile T2D

CAPN10 genindeki SNP-43 polimorfizmi ve Tip 2 Diabetes -

Uçaryılmaz ve ark. 
ve metabolik fenotipler arasında istatistiksel olarak anlamlı bir ilişki bulunmadığı bununla birlikte, popülasyonda $\mathrm{G} / \mathrm{G}$ genotipini taşıyan bireylerin G/A ve A/A genotipini taşıyanlara göre \%19 daha yüksek T2D riski taşıdığını ayrıca Ailesel temelli çalışmaların meta analizinde ise ilginç olarak T2D'li heterezigot ebeveynlerin, T2D'li çocuklarında SNP-44 C nadir allelinin daha fazla aktarıldığ gözlendi (31). Çin popülasyonunda yapılan çalışmada ise SNP43 için A/A genotipine rastlanmadığ 1 ve SNP-43'ün insülin direnci üzerinde etkili olmadığı bildirildi (32). Tunus popülasyonunda SNP43'ün A alleli, İspanyol popülasyonunda SNP-44 T/T genotipi, Batı Hindistan popülasyonunda bir çalışmada SNP-63'te T aleli ve Türk popülasyonundan bir çalışmada da SNP-44 polimorfizminde T/C genotipinin T2D gelişme riskini artırdığı bildirildi (33-36).

Bizim çalışmamızda CAPN10 geninde bulunan SNP-44, -43 ve -137'nin T2D gelișimi ve hastalığın klinik fenotipleri arasındaki ilişki araştırıldı. Bulgularımıza göre sadece SNP-43 tip 2 diyabet ile anlamlı şekilde ilişkili bulundu. Çalışma gruplarımızın allel dağılımı bakımından Hardy-Weinberg dengesinde olması sonuçlarımızı güçlendiren bir etken olmasına rağmen popülasyon büyüklüğümüz çalışmamızın en önemli limitasyonudur. Bu nedenle bir ön rapor niteliğindeki bu çalışma sonuçlarının hasta ve kontrol sayısı artırılarak daha büyük bir örneklem grubunda teyit edilmesine ihtiyaç vardır. Ayrıca CAPN10 genindeki diğer varyantların da taranması ve tüm sonuçların birlikte yeniden değerlendirilmesi CAPN10 geninin T2D gelişimine katkısının anlaşılmasında yararlı olacaktır.

\section{Teșekkür}

Bu çalışma, Selçuk Üniversitesi Bilimsel Araştırma Projeleri tarafından desteklenmiştir. Proje no: 09202049

\section{Kaynaklar}

1. Alberti KG, Zimmet PZ. Definition, diagnosis and classification of diabetes mellitus and its complications. Part 1: diagnosis and classification of diabetes mellitus provisional report of a WHO consultation. Diabet Med 1998;15:539-53.

2. Brestoff JR, Artis D. Immune regulation of metabolic homeostasis in health and disease. Cell 2015;161:146-60.

3. Vaiserman A, Lushchak O. Developmental origins of type 2 diabetes: Focus on epigenetics. Ageing Res Rev 2019;55:100957.

4. Weyer C, Bogardus C, Mott DM, Pratley RE. The natural history of insulin secretory dysfunction and insulin resistance in the pathogenesis of type 2 diabetes mellitus. J Clin Invest 1999;104:787-94.

5. Lim EL, Hollingsworth KG, Aribisala BS, Chen MJ, Mathers JC, Taylor R. Reversal of type 2 diabetes: normalisation of beta cell function in association with decreased pancreas and liver triacylglycerol. Diabetologia 2011;54:2506-14.

6. Donath MY, Shoelson SE. Type 2 diabetes as an inflammatory disease. Nat Rev Immunol 2011;11:98-107.

7. Zeggini E, Scott LJ, Saxena R, Voight BF. Meta-analysis of genome-wide association data and large-scale replication identifies additional susceptibility loci for type 2 diabetes. Nat Genet 2008;40:638-45.

8. Guja C, Gagniuc P, Ionescu-Tirgovişte C. Genetic factors involved in the pathogenesis of type 2 diabetes. Proc Rom Acad Series B 2012;1:44-61.

9. Barroso I, Luan J, Middelberg RP, et al. Candidate gene association study in type 2 diabetes indicates a role for genes involved in beta-cell function as well as insülin action. PLoS Biol 2003;1:E20.

10. Panico P, Salazar AM, Burns AL, Ostosky-Wegman P. Role of calpain-10 in the development of diabetes mellitus and its complications. Arch Med Res 2014;45:103-15.

11. Horikawa Y, Oda N, Cox NJ, et al. Genetic variation in the gene encoding calpain-10 is associated with type 2 diabetes mellitus. Nat Genet 2000;26:163-75.

12. Suzuki K, Hata S, Kawabata Y, Sorimachi H. Structure, activation, and biology of calpain. Diabetes 2004;53:12-8.

13. Marshall C, Hitman GA, Partridge CJ, et al. Evidence that an isoform of Calpain-10 is a regulator of exocytosis in pancreatic $\beta$-cells. Mol Endocrinol 2005;19:213-24.

14. Dong B, Liu R. Characterization of endogenous and recombinant human calpain-10. Biochimie 2008;90:1362-71.

15. Ridderstråle M, Nilsson E. Type 2 diabetes candidate gene CAPN10: first, but not last. Curr Hypertens Rep 2008;10:19-24.

16. Baier LJ, Permana PA, Yang X, et al. A Calpain-10 gene polymorphism is associated with reduced muscle mRNA levels and insulin resistance. J Clin Invest 2000;106:R69 R73.

17. Evans JC, Frayling TM, Cassell PG, et al. Studies of association between the gene for Calpain-10 and Type 2 Diabetes Mellitus in United Kingdom. Am J Hum Genet 2001;69:544-52

18. Cassell PG, Jackson AE, North BV, et al. Haplotype combinations of calpain 10 gene polymorphisms associate with increased risk of impaired glucose tolerance and type 2 diabetes in South Indians, Diabetes 2002;51:1622-28.

19. Garant MJ, Kao WH, Brancati F, et al. SNP43 of CAPN10 and the risk of type 2 Diabetes in African-Americans, The Atherosclerosis Risk in Communities Study, Diabetes 2002;51: 231-7.

20. Hoffstedt J, Ryden M, Lofgren P, Orho-Melander M, Groop L, Arner P. Polymorphism in the Calpain 10 gene influences glucose metabolism in human fat cells, Diabetologia 2002; 45:276-82.

21. Malecki MT, Moczulski DK, Klupa T, et al. Homozygous combination of calpain 10 gene haplotypes is associated with type 2 diabetes mellitus in a Polish population, Eur J Endocrinol 2002;146:695-9.

22. Horikawa Y, Oda N, Yu L, et al. Genetic variations in Calpain-10 gene are not a major factor in the occurrence of Type 2 Diabetes in Japanese. J Clin Endocrinol Metab 2003;88:244-7.

23. Horikawa Y. Calpain-10 (NIDDM1) as a susceptibility gene for common type 2 diabetes. Endocrine Journal 2006;53:567-76.

24. Tsai HJ, Sun G, Weeks DE, et al. Type 2 Diabetes and three Calpain-10 gene polymorphisms in Samoans: No Evidence of Association. Am J Hum Genet 2001;69:1236-44.

25. Elbein SC, Chu W, Ren Q, et al. Role of calpain-10 gene variants in familial type 2 diabetes in Caucasians. J Clin Endocr Metab 2002;87:650-4.

26. Fingerlin TE, Erdos MR, Watanabe RM, et al. Variation in three single nucleotide polymorphisms in the calpain-10 gene notassociated with type 2 diabetes in a large Finnish cohort. Diabetes 2002;51:1644-8.

27. Rasmussen SK, Urhammer SA, Berglund L, et al. Variants within the Calpain-10 gene on chromosome 2q37 (NIDDM1) and relationships to Type 2 Diabetes, insulin resistance and impaired acute insulin secretion among Scandinavian Caucasians. Diabetes 2002;51:3561-7.

28. Ortho-Malender M, Klannemark M, Svensson MK, Ridderstrale M, Lidgren CM, Groop L. Variants in the calpain-10 gene predispose to insülin resistance and elevated free fatty acid level. Diabetes 2002;51:2658-64.

29. Daimon M, Oizumi T, Saitoh T, et al. Calpain 10 gene polymorphisms are related, not to type 2 diabetes, but to increased serum cholesterol in Japanese. Diabetes Res Clin Pract 2002;56:147-52.

30. Shima Y, Nakanishi K, Odawara M, Kobayashi T, Ohta H. Association of the SNP-19 genotype 22 in the calpain-10 gene with elevated body mass index and hemoglobin A1c levels in Japanese. Clin Chim Acta 2003;336:89-96.

31. Song Y, Niu T, Manson JE, Kwiatkowski DJ, Liu S. Are variants in the CAPN10 gene related to risk of Type 2 diabetes? A quantitative assessment of population and familybased association studies. Am J Hum Genet 2004;74:208-22.

32. Wu B, Takahashi J, Fu M, Cheng H, Matsumura S, Taniguchi H. Variants of calpain-10 gene and its association with type 2 diabetes mellitus in a Chinese population. Diabetes Res Clin Pract 2005;68:155-61.

33. Kifagi C, Makni K, Mnif F, Boudawara M, Hamza N, Rekik N. Association of calpain-10 polymorphisms with type 2 diabetes in the Tunisian population. Diabetes Metab 2008;34:273-8.

34. Saez ME, Gonzalez-Sanchez JL, Ramirez-Lorca R, et al. The CAPN10 gene is associated with insulin resistance phenotypes in the Spanish population. PloS ONE 2008;3:e2953

35. Adak S, Sengupta S, Chowdhury S, Bhattacharyya M. Co-existence of risk and protective haplotypes of Calpain 10 gene to type 2 diabetes in the eastern Indian population. Diab Vasc Dis Res 2010;7:63-8.

36. Demirci H, Yurtcu E, Ergun M, Yazıcı A, Karasu C, Yetkin I. Calpain-10 SNP-44 gene polymorphism affects susceptibility to type 2 diabetes mellitus and diabeticrelated conditions. Genet Test 2007;12:305-10. 